\title{
Tackling Climate Change in China: A Hybrid Approach
}

\author{
Giuseppe PODERATI \\ PhD candidate, Research Institute Environmental Law, Wuhan University, \\ Wuhan, China \\ gpoderati@gmail.com
}

\author{
Shutian $O U$ \\ Lecturer, Kenneth Wang School of Law, Soochow University, Suzhou, China \\ stou@suda.edu.cn
}

\begin{abstract}
This article argues that climate change policies should be designed as far as possible with the involvement of civil society at large, as it is an existential problem that concerns the whole of humanity. It is suggested that in the Chinese context, the legal system and political decision-making processes could better address climate change for example, through the participatory processes promoted by the Rio Declaration on Environment and Development 1992 and subsequent instruments. The article explores the possibility of adopting a hybrid approach in China by developing an interactive platform linking the relevant components of civil society in order to gather critical expertise and insights from the community as a whole. A hybrid approach would be directed at combining the current top-down approach with a bottom-up approach, which would potentially contribute to an increase in transparency and accountability in legislative and political decision-making processes to produce the best possible legal approaches and policy strategies for addressing climate change.
\end{abstract}

\section{Keywords}

China - climate change - law - policy - top-down approach - bottom-up approach hybrid approach 
It is broadly recognized that the world continues to be greatly affected by the phenomenon of climate change. ${ }^{1}$ Developed and developing countries, as well as countries in transition, are increasingly concerned about the effects of climate change, with the linked effects of heightened rates of desertification, extreme weather events, forest fires, flooding and so forth. Further, climate change is seen as contributing to increased resource scarcity, including water and food security issues, leading in some cases to armed conflict and mass migration around the world, and triggering socio-economic and political instability. ${ }^{2}$

China is also under significant environmental pressure, with at least four major factors at play: the fragility of many of its ecosystems, its huge population, the scarcity of natural resources, and high consumption growth rates. ${ }^{3}$ These factors brought the Chinese Government to consider climate change as an issue of national security. ${ }^{4}$ Thus considered, Chinese leaders have been preparing their society for substantive change, with the concept of ecological

1 See generally, the latest reports of the Intergovernmental Panel on Climate Change (IPCC) $<$ www.ipcc.ch/index.htm $>$.

2 Abrahm LUSTGARTEN, 'The Great Climate Migration' The New York Times (New York, 23 July 2020) <www.nytimes.com/interactive/2020/07/23/magazine/climate-migration .html >. Alex DE SHERBININ, 'Impacts of Climate Change as Drivers of Migration' Migration Policy Institute (23 October 2020) <www.migrationpolicy.org/article/impacts-climate -change-drivers-migration>. Cristiano D'ORSI, Asylum-Seeker and Refugee Protection in Sub-Saharan Africa: The Peregrination of a Persecuted Human Being in Search of a Safe Haven (London/New York: Routledge, 2015).

3 Guangtao WANG, 'The State of China's Cities 2014/2015' China Science Center of International Eurasian Academy of Sciences, China Association of Mayors, Urban Planning Society of China and UN-Habitat, 2014. Min WANG and Dongying WEI, Population and Natural Resources case study: What are the challenges of meeting the resource needs of a very large population? AAG Center for Global Geography Education, <http://cgge.aag.org/ PopulationandNaturalResourcesie/CS_China_Julyog/CS_China_Julyo9_print.html>. See, Norman MYERS, 'China's Approach to Environmental Conservation' (1976) 5 Envtl Aff 33.

4 Halia CZOSNEK, 'The National Security Implications of Anthropogenic Climate Change on Health: A Case Study on China' Small Wars Journal (7 May 2019) <https://small warsjournal.com/jrnl/art/national-security-implications-anthropogenic-climate-change -health-case-study-china>. John KEMP, 'Column: China's national security and carbonneutral target' Reuters (24 September 2020) <www.reuters.com/article/uk-china-energy -kemp-idUKKCN26FigN>. See further, GUO Wei, ‘全国人大常委会听取审议环境状况和 环保目标完成情况报告' ['Standing Committee of the National People's Congress listened to and reviewed the Report on Environmental Condition and Completion of Environmental Protection Goals'] China Environment News (25 April 2017) 1. 
civilization $^{5}$ (shengtai wenming 生态文明) becoming a national goal ${ }^{6}$ as well as being incorporated into the Chinese Constitution ${ }^{7}$ and environmental legislation. ${ }^{8}$ Arthur HANSON, former international chief advisor to the China Council for International Cooperation of Environment and Development, states:

Ecological civilization is being used by the People's Republic of China (PRC) to provide a coherent conceptual framework for adjustments to development that meets 21st century challenges. It differs from sustainable development in the emphasis placed on political and cultural factors, as well as on defining new relationships between people and nature that would permit living well, and within the eco-environmental bounds of planet Earth. ${ }^{9}$

From the perspective of establishing participatory processes, this is a relevant aspect, since ecological civilization is trying to re-orient the various components of contemporary Chinese civil society with the natural environment, taking into account new eco-environmental boundaries of planetary ecosystem. The main intent is to build institutions on ideas of ecological civilization and rule of law by establishing appropriately stringent legal frameworks to ensure that economic development meaningfully prioritizes environmental

5 See, eg, ‘胡锦涛在中国共产党第十七次全国代表大会上的报告” ['HU Jintao's Report Representing the 16th Central Committee of the Communist Party of China (CCP) in the 17th National Congress of the CCP'] (October 25 2007) <http://cpc.people.com.cn/ $\mathrm{GB} / 64093 / 67507 / 6429846 . h t m l>$.

6 Former President HU Jintao stated: 'We must give high priority to making an ecological civilization, work hard to build a beautiful country, and achieve lasting and sustainable development of the Chinese nation'. See, 'Report at 18th 17th Party Congress' (November 11, 2012) <http://v.china.com.cn>.

7 See 'Full Text of Constitution of Chinese Communist Party, revised and adopted at the 18th CCP National Congress on November 14, 2012 (Beijing: Xinhua News, November 18, 2012)' $<$ http://news.xinhuanet.com/english/bilingual/2012-11/18/c_131982634.htm>.

8 Constitution of the PRC, as amended in 2018, preamble and Articles 89(6); Environment Protection Law 2014, Article 1: 'This law is developed for the purposes of ... promoting ecological civilization, and enhancing sustainable economic and social development.'; see further, Ben BOER, Rowena CANTLEY-SMITH, QIN Tianbao, 'Special Issue: Ecological Civilization and Environmental Governance' (2O2O) 4(2) Chinese Journal of Environmental Law, 121.

9 Arthur HANSON, 'Ecological Civilization in the People's Republic of China: Values, Action, and Future', ADB 2019. 
protection. ${ }^{10}$ This, in point of fact, reflects a real and promising change in China's environmental protection regime, as noted by ZHANG et al: 'China has enacted a new Environmental Protection Law (EPL) that seeks to harmonize economic and social development with environmental protection and for the first time establishes clear requirements for the construction of an ecological civilization'.11

From a functional point of view, it is essential to find a way to be more responsive to the challenges posed by climate change-related issues. China, by means of its Five Year Plans, is showing a dramatic determination in setting policies and taking measures to, inter alia, mitigate and adapt to climate change impacts both at the national and international level. ${ }^{12}$ As President XI Jinping stated at the Paris climate change talks: 'Tackling climate change is a shared mission for mankind ... Let us join hands to contribute to the establishment of an equitable and effective global mechanism on climate change, work for global sustainable development at a high level and bring about new international relations featuring win-win cooperation. ${ }^{13}$ In December 2020, at the Climate Ambition Summit, XI Jinping significantly stated: '... we need to raise ambition and foster a new architecture of climate governance where every party does its part. Following the principle of common but differentiated responsibilities, all countries need to maximize actions in light of their respective national circumstances and capabilities. At the same time, developed countries need to scale up support for developing countries in financing,

10 'To create an ecological civilization, China must address the root cause of the deterioration of the environment - ie, pollution - so as to reverse the trend, to ultimately create a sound working and living environment, and to contribute to China's global ecological security' see, Qian SUN and Jack TUHOLSKE, 'An Exploration of and Reflection on China's System of Environmental Public Interest Litigation' (2017) 47 ELR 10497, 10498-99.

11 Bo ZHANG, Cong CAO, Junzhan GU and Ting LIU, 'A New Environmental Protection Law, Many Old Problems? Challenges to Environmental Governance in China', (2016) 28 Journal of Environmental Law 325-335. 'Environmental Protection Law of the People's Republic of China' <http://www.china.org.cn/english/environment/34356.htm>; see also Alex WANG, 'The Search for Sustainable Legitimacy: Environmental Law and Bureaucracy in China' (2013) 37 Harvard Environmental Law Review 365.

12 On September 23, 2019, President Xi Jinping's special representative, State Councillor and Foreign Minister Wang YI said in his speech, 'climate change is a common challenge to all countries. To jointly tackle this challenge and protect the planet we all call home will be a journey critical to the future and destiny of humankind. We must uphold multilateralism' (24 September 2019) <www.fmprc.gov.cn/mfa_eng/zxxx_662805/t1701330.shtml>.

13 'Highlights-World leaders open Paris climate change talks' Reuters, November 30, 2015 $<$ https://www.reuters.com/article/climatechange-summit-highlights-idUSLiNi3 PoFE 20151130>. 
technology and capacity building.. ${ }^{14}$ China undoubtedly wants to assert its leadership in the continuing international climate change negotiations; however, this entails that the Chinese Central Government has a major responsibility for facilitating the implementation of the 2015 Paris Agreement on climate change and the achievement of Sustainable Development Goals (SDG s) at the domestic level as well..$^{15}$

The aim of this article is to explore the adoption of a hybrid approach in China by developing an interactive platform linking the relevant components of civil society in order to gather crucial expertise and insights from the community as a whole. The main research questions are the following: Would a hybrid approach be able to combine the current top-down approach with a bottomup approach that would potentially contribute to an increase in transparency and accountability in legislative and political decision-making processes? Are there any signs of the application of a hybrid approach in China? Within these research interrogatives, the authors highlight the current main characteristics of the top-down approach adopted in China, namely: the Five Years Plans, the role of State-Owned Enterprises (sOEs), the so-called command and control regulations, the establishment of the Ministry of Ecology and Environment, and the empowerment of the Procuratorate. The authors use a textual analysis methodology mixed with a descriptive one that implies the activity both of observing and analysing the above-stated characteristics. Importantly, a contextual method is adopted as well, with an analysis regarding the elaboration of given laws or policies chiefly in the Chinese context. In addition, a comparative methodology is also used for describing the positive and encouraging experiences of the adoption of the bottom-up approach in Italy and in China's Special Administrative Region of Hong Kong.

Section I sets out the current conditions of China's climate change policy indicating a 'top-down' approach by the Central Government. Section II analyses the potential alternative approaches that China could - according to the authors - take into account in its legislative and political decision-making processes to use a 'bottom-up' approach and a top-down approach to more

14 'Xi Jinping Addresses Climate Ambition Summit', December 15, 2020 <http://au.china -embassy.org/eng/zgxw_4/t1840219.htm>.

15 Yun GAO, 'China's response to climate change issues after Paris Climate Change Conference' (14 October 2016) (Department of Technology and Climate Change, China Meteorological Administration, Beijing China), 7 (2016) ScienceDirect, Advances in Climate Change Research pages 235 and 240, <www.sciencedirect.com/journal/ advances-in-climate-change-research $>$. Matt MCGRATH, 'Climate change: China aims for carbon neutrality by 206o' (Beijing, 22 September 2020) <www.bbc.com/news/ science-environment-54256826>. 
effectively respond to climate change. With the adoption of these two, in order to produce a hybrid approach it is suggested that legal and political solutions could be formulated that could be more pragmatic, aiming at reducing the vulnerability of cities, towns, villages and communities to climate change effects. With the authors' recognition of the importance of the principle and concept of environmental democracy, ${ }^{16}$ the feasibility of the bottom-up approach in China is assessed, exploring questions about its possible implementation. The article concludes that the effectiveness of the bottom-up approach would necessarily rely on the political will of the Chinese Government and of the regional economic and political operators (eg, State Owned Enterprises) that need to establish effective measures to meet their obligations in fighting climate change.

\section{2 \\ China's Adoption of a Top-Down Approach in Responding to Climate Change Effects}

As is well known, the Chinese political system encourages the continuing leadership and governance of the Chinese Communist Party, ${ }^{17}$ taking account of the presence of a range of minor parties. ${ }^{18}$ Without assuming any existing

16 'Environmental democracy is rooted in the idea that meaningful participation by the public is critical to ensuring that land and natural resource decisions adequately and equitably address citizens' interests. Rather than setting a standard for what determines a good outcome, environmental democracy sets a standard for how decisions should be made'; see Jesse WORKER, Stephanie RATTÉ, 'What does environmental democracy look like?', (World Resources Institute, 29 July 2014) <www.wri.org/blog/2014/o7/what-does -environmental-democracy-look $>$. The article by Marjan PEETERS, 'Judicial Enforcement of Environmental Democracy: a Critical Analysis of Case Law on Access to Environmental Information in the European Union', (2020) 4 Chinese Journal of Environmental Law 13, 14, also canvasses various definitions of environmental democracy.

17 As noted by the Ministry of Foreign Affairs: 'China is a country of many political parties. Apart from the CPC, which is in power, China has eight non-Communist parties. Since their founding the latter have established cooperative relations with the CPC to different extents'. <https://www.fmprc.gov.cn/mfa_eng/ljzg_665465/zgjk_665467/3579_665483/t17851 .shtml $>$. The relationship between these parties and the ruling Communist Party is thus a cooperative, not competitive, one. See Guangxin SHI, Shuwen CHEN, 'The Historical Process and Basic Experience of Upholding and Strengthening the Communist Party of China Leadership since Reform and Opening up' [2019] 415 Advances in Social Science, Education and Humanities Research, 317. Xi WANG, Lu KUN, Environmental Law in China, (2nd edn Wolters Kluwer 2017), 23.

18 Explainer: CPC-led multi-party cooperation and political consultation <https://news .cgtn.com/news/2019-11-21/Graphics-China-s-party-system-explained-LNmPMninCg/ index.html>. Susan V. LAWRENCE, Michael F. MARTIN, 'Understanding China's Political 
superiority of the Western sphere of the world, one ought to objectively note that in China the concept of 'middle class' is different from what may be commonly understood in other parts of the world. In somewhat simplistic terms, there is an ever-growing social class that has become wealthy or at least meaningfully able to live above the poverty threshold by means of rapid economic growth. ${ }^{19}$

In the years since the industrial revolution, the middle classes in Europe and North America increasingly promoted market-led economies, liberal values, and democracy, and most importantly generating a culture of civic participation. In contrast, we observe that Chinese concepts of civic participation ${ }^{20}$ differ from those understood in the West, and as a consequence, there is a great deal of dependence on the views of central, provincial and local governments, with the Chinese Communist Party's top-down approach predictably also manifested in the legislative and political decision-making processes that address environmental degradation and climate change-related issues.

System' (Congressional Research Service, 20 March 2013). Randall PEERENBOOM, Courts as Legislators, The Rule of Law in China Series: Policy Brief 1 , The Foundation for Law, Justice and Society, Oxford 2006. Randall PEERENBOOM, Economic and Social Rights: The Role of Courts in China (San Diego International Law Journal 2011), 322. Jiang JIE, Huang FAHONG, China to a supervision system with Chinese characteristics: experts, (23 October 2017), Alwihda Info <www.alwihdainfo.com/Latest-reform-leading-China -to-a-supervision-system-with-Chinese-characteristics-experts_a58783.html $>$. Further, Xinhua, 'China Focus: New law to bring supervisory network against corruption', Editor Fang LI, (3 March 2018) <www.xinhuanet.com/english/2018-03/04/c_137015472.htm>. And yet, The Supervisory System Improved, Beijing Review, Editorial (12 March 2018) <www.bjre view.com/Nation/201803/t20180319_80o12397o.html>.

19 'XI declares "complete victory" in eradicating absolute poverty in China' Xinhuanet (Beijing, 25 February 2021) <www.xinhuanet.com/english/2021-02/25/c_139765861.htm>. Zhang YUAN, Guanghua WAN, and Niny KHOR, 'The Rise of the Middle Class in the People's Republic of China' ADB 2011. Peter HEFELE, Andreas DITTRICH, 'China's Middle Class A Driving Force for Democratic Change or Guarantor of the Status Quo?', KAs International Reports 2011. Eileen Yuk-Ha TSANG, The New Middle Class in China, (1st ed, Macmillan Publishers Limited, London, 2014). JI Siqi 'China looks to boost middle class as it wraps up XI Jinping's anti-poverty drive' South China Morning Post (30 November 2020) <https:// www.scmp.com/economy/china-economy/article/3111929/china-looks-boost-middle -class-it-wraps-xi-jinpings-anti>. Chiu-Ti JANSEN, 'China wants to be a middle-income country without a middle class', Nikkei Asia (27 January 2020), <https://asia.nikkei.com/ Opinion/China-wants-to-be-a-middle-income-country-without-a-middle-class > .

20 Chinese leaders qualify their system as 'socialist democracy'. The Chinese Communist Party acts in the interests of the people, and, on its own terms, it represents the will of the people. In this way, the CCP is representative of the people and is of a form of democracy. However, all in all, it is quite a different system from Western democracies. 


\subsection{Five-Year Plans}

China has issued Five-Year Plans since 1953. This legal and political instrument is used by the Central Government to give continuity to what it is recognized as the 'most remarkable economic transformation in history' ${ }^{21}$ lifting more than 8 oo million people out of poverty ${ }^{22}$ and moving towards sustainable economic development. It is worth noting that the Chinese legal system is built around a socialist constitution (grundnorm) that through its legal provisions provides the foundation of legitimacy for the Five-Year Plans. ${ }^{23}$

According to Article 62(9) of the Constitution, the National People's Congress (NPC) exercises power 'to examine and approve the plan for national economic and social development and the report for its implementation'. ${ }^{24}$ The exercise of this power by the N PC appears to be well proven in the fight against environmental degradation, pollution and climate change by setting up specific targets and triggering broad systemic reforms. ${ }^{25}$ All these plans offer the opportunity for both Chinese and foreign scholars as well as observers to gain a better understanding of China's way of scaling up measures against pollution and climate change. In a nutshell, though not perfect, it is possible to discern that China might be able to succeed in generating more balanced growth with the use of green technologies transitioning to a low-carbon society in the near future. ${ }^{26}$

21 Joseph STIGLITZ, 'Development in defiance of the Washington consensus' The Guardian (London, 13 April 2006) <www.theguardian.com/commentisfree/2006/apr/13/comment .business>.

22 'The World Bank in China', <https://www.worldbank.org/en/country/china/overview>.

23 Hualing FU, Xiaobo ZHAI, 'What makes the Chinese Constitution socialist?' [2018] 16 International Journal of Constitutional Law, 655-663.

24 Article 62(9) Constitution of People's Republic of PRC (adopted on 4 December 1982, amended 11 March 2018).

25 See the work and activities of the National People's Congress Environment Protection and Resources Conservation Committee. Lei ZHANG, Guizhen HE, Arthur P.J. MOL, 'China's new environmental protection law: A game changer? Environmental Development', 13 (2015) 1-3.

26 'Chinese photovoltaic businesses embrace low-carbon development' Global Times (12 April 2021) <https://www.globaltimes.cn/page/202104/1220824.shtml>. 'Chinese stateowned oil firms are planning more low-carbon initiatives, as part of China's target for carbon emissions to peak before 2030 and to achieve carbon neutrality by 2060' see, 'Chinese oil firms plan more low-carbon initiatives' Argus Media (15 April 2021) <https://www.argus media.com/en/news/2205453-chinese-oil-firms-plan-more-lowcarbon-initiatives?back ToResults=true $>$. 'What is green finance, and why is it important to China's carbon neutral goal' South China Morning Post (2 April 2021) <https://www.scmp.com/news/china/ 
Of note, within the dynamic of the top-down approach, the NPC, as the country's top organ, exercises national legislative power, while the State Council is the executive organ with competence to formulate administrative regulations concerning the environmental field. ${ }^{27}$ Following on from the UNFCCC COP21 Conference held in Paris in 2015, the 13th Five-Year Plan highlighted the Chinese target to become a 'moderately prosperous society' centred on sustainable development. ${ }^{28}$ It appears that China wants to create sustainable development based on innovation and use of best available technologies in responding to climate change. Pursuant to chapter 46 of the 13th Five-Year Plan, it will be necessary to carry out the following set of programs and activities, namely: (i) Reduction of total carbon emissions per unit of GDP by $60-65 \%$ from 2005 levels by 2030 and peak carbon emissions by 2030; (ii) Increasing energy efficiency by ensuring an energy mix arrangement; (iii) Incentivize green transportation (eg, electric vehicles, sustainable mass rapid transports and so forth); (iv) Mitigation of climate change impacts through the sustainable use of land; (v) Promoting the Circular Economy, also known as Zero Waste Economy. ${ }^{29}$ Hence, China is realistically and intelligently

politics/article/3128167/what-green-finance-and-why-it-important-chinas-carbon -neutral>.

27 Jianfu CHEN, Chinese Law: Context and Transformation: Revised and Expanded Edition, Martinus Nijhoff Publishers, Leiden, Boston 2008. Linhan SU, Administrative Enforcement in China,<https://law.yale.edu/china-center/resources/administrative-enforce ment-china $>$.

28 'China's development policies are focused on five guiding principles of 'innovative, coordinated, green, open, and shared development. At the same time, the 13th Five Year Plan sets peak targets for carbon emissions and energy and water consumption, as well as goals for increasing efficiency of industries and eliminating outdated or overcapacity production facilities, increasing energy production from renewables, and developing green infrastructure', see, the 13th Five-Year Plan (London School of Economics and Political Science, Executive 2016), <www.lse.ac.uk/GranthamInstitute/law/13th-five-year-plan/>.

29 'We will implement a plan for guiding circular development, encourage the circular use of resources between production and society, and accelerate efforts to recycle resources from refuse. We will make coordinated plans for industrial layouts based on material flow and industrial linkage, encourage industrial parks to adopt a more circular operational flow, establish hybrid industry-agriculture circular economy demonstration zones, and promote the coupled growth of enterprises, industrial parks, and industries. We will facilitate the recovery and utilization of mineral resources from urban waste, ensure that resources from industrial solid waste and other types of mass refuse are recycled and reused, accelerate the establishment of systems for the recycling or safe disposal of urban kitchen waste, construction refuse, and textile waste, and develop remanufacturing in line with standards. We will put into effect an extended producer responsibility system. We will improve recycling networks for renewable resources and strengthen coordination between the recycling of sorted household waste and the recycling of renewable 
moving towards the decarbonization of its economy and the achievement of the climate neutrality by 2060. ${ }^{30}$ In order to achieve the goal of peak carbon emissions, the State Council issued its Carbon Peaking Action Plan by 2030 on October 24, 2021. ${ }^{31}$

On March 11, 2021, the 4th Session of the 13th National People's Congress voted and approved the 14th Five-Year Plan for National Economic and Social Development (2021-2025) and the Outline of Vision Goals for 2035, which provided that 'Implementing the nationally determined contribution target for climate change in 2030, and formulating an action plan for peaking carbon emissions before 2030' in Section 'actively respond to climate change' of Chapter 38 'continuous improvement of environmental quality'.32 The separate section aiming at responding to climate change in 14th Five-Year Plan shows the government's ambition to fulfill President XI Jinping's commitment to the achievement of peak carbon emissions by 2030 and climate neutrality economy by 206o. ${ }^{33}$ Specifically, the 14th Five-Year Plan to actively respond to climate change includes the following aspects: (a) Improve the dual control system of total energy consumption and intensity, and focus on controlling fossil energy consumption; (b) Implement a system with carbon intensity control as the mainstay and total carbon emission control as a supplement to support qualified localities, key industries and key enterprises to take the lead in reaching the peak of carbon emissions; (c) Promote the clean, low-carbon,

resources'. See, State Council, 13th Five-Year Plan for the National Economic and Social Development of the People's Republic of China, 17 March 2016, Chapter 46, Section 1. See also 12th Five-Year Plan for the National Economic and Social Development of the People's Republic of China, 16 March 2011, Chapter 21, Section 1, calling for 'structural adjustments' in industrial, energy and other key systems.

30 Baiping CHEN, Lars FÆSTE, Rune JACOBSEN, Ming TECK KONG, Dylan LU, and Thomas PALME, 'How China Can Achieve Carbon Neutrality by 206o' (2020) Boston Consulting Group. <www.bcg.com/publications/2020/how-china-can-achieve -carbon-neutrality-by-206o>.

31 Carbon Peaking Action Plan by 2030, The State Council, <www.mee.gov.cn/zcwj/gwywj/ 202110/t20211026_957879.shtml>.

32 The 14th Five-Year Plan for National Economic and Social Development and proposals For Long-term Goals for the 2035 vision, <http://www. gov.cn/xinwen/2021-03/13/con tent_5592681.htm>.

33 Eamon BARRETT, 'China is set to ratify its 14th five-year plan. What to expect from its latest economic road map' Fortune.com (2 March 2021) <https://fortune.com/2021/o3/o2/ china-five-year-plan-what-is-two-sessions/>. Michal MEIDAN, Philip ANDREWS-SPEED, Yan QIN, 'Key issues for China's 14th Five Year Plan' (March 2021) The Oxford Institute for Energy Studies. 'The focus was still on the Paris Accord target to peak carbon by 2030 and to reduce carbon intensity of the economy by $18 \%$ in the coming five years' see, Bert HOFMAN, 'China's 14th Five-Year Plan: First Impressions' National University of Singapore, East Asian Institute National University of Singapore, EAI Commentary, (2021). 
safe and efficient use of energy, and deepen the low-carbon transformation of industry, construction, and transportation; (d) Increase greenhouse gas control; (e) Improve the carbon sink capacity of the ecosystem. ${ }^{34}$

Thus characterized, the Five-Year Plan is the pivotal document produced through a top-down policy approach that sheds light on China's path towards a low-carbon society by accelerating the transition to the use of renewable energies, shifting away from the traditional fossil fuel-based economy responsible for the current environmental degradation and climate-induced natural disasters.

\subsection{Command and Control Regulation}

Within the dynamics of the top-down approach, the Chinese Government frequently uses command and control ${ }^{35}$ environmental regulations attempting to decrease the greenhouse gas emissions that cause climate change. This is commonly considered by scholars as a 'traditional approach to environmental law that relies on the administrative enforcement of technology-based standards ... The performance standards usually are specific and defined either by statute or administrative regulation. They are mostly enforced through a system of permits or an enforced disclosure regime backed up by inspections.' ${ }^{36}$ The Chinese Government is fully oriented to creating an effective 'inspection system $^{\prime 37}$ at the local level in order to control polluters, not only private companies, but also SOE s. In this way, even local authorities will be more incentivized to enforce the environmental norms, thereby increasing transparency and accountability.

One further observation of a general character must be made here. By way of background, in China collusion and corruption are said to be persistent factors in social relationships. ${ }^{38}$ These can put in peril some of the policies not

34 14th Five-Year Plan (n 31) 'Section 4. Actively respond to climate change', 94.

35 Qin YE, Shaoqing DAI, Gang ZENG, Research on the effects of command-and-control and market-oriented policy tools on China's energy conservation and emissions reduction innovation, Tandfonline (27 December 2017), <www.tandfonline.com/doi/abs/10.1080/1004 2857.2017.1418273>. Li WANHING, Yue GU, Liu FANG, Ce LI, The effect of commandand-control regulation on environmental technological innovation in China: a spatial econometric approach. 2019 Environ Sci Pollut Res Int 26(34).

36 Eric W. ORTS, Environmental Law with Chinese Characteristics (11 William \& Mary Bill of Rights Journal 2003) 545, 558 .

37 'China plans tougher goals, beefed-up inspections in war on smog' Reuters (17 March 2018) <www.reuters.com/article/us-china-parliament-environment/china-plans-tougher -goals-beefed-up-inspections-in-war-on-smog-idUSKCN1GTo8H $>$.

38 'The main form of corruption is embezzlement of poverty funds; there is more individual than group corruption; and political accountability is the most important form 
profitable for either the public or private sectors. Government entities or officials could be quite influential, and they can bypass norms and standards, for instance, regulating the environmental and social impact assessment that is a useful instrument in mitigation and adaptation of climate change impacts. Local governments, with foreign investors or just the officials of the soE s, ${ }^{39}$ for instance, could have specific economic interests which are in conflict with national climate change policies. ${ }^{40}$ Here, one of the limits of the top-down approach is that it allocates power among few economic or political entities, raising crucial issues of transparency and accountability.

\subsection{State-Owned Enterprises}

Another distinctive characteristic of the Chinese top-down approach to climate change policy is grounded in the role played by State-Owned Enterprises (SOE s). In a fast-growing and changing economy, SOE s are nowadays considered a huge economic cost. ${ }^{41}$ Thus considered, the Central Government should ideally diminish soes' privileged position within the economic and political system within the medium term. As a matter of fact, the Chinese Government is willing to change the soEs' legal structure. The debate is now focusing on whether they should be characterized by mixed ownership ${ }^{42}$ (with the crucial

of accountability', see, Shuai WU, Tom CHRISTIANSEN, Corruption and Accountability in China's Rural Poverty Governance: Main Features from Village and Township Cadres Tandfonline (19 May 2020) <www.tandfonline.com/doi/full/10.108o/o190o692.2020.1765 799? scroll=top\&needAccess=true $>$. 'XI Jinping's anticorruption campaign has targeted some of China's biggest political and military figures and implicated tens of thousands of cadres' Macabe KELIHER, and Hsinchao WU. 'Corruption, Anticorruption, and the Transformation of Political Culture in Contemporary China' (2016) 75(1) The Journal of Asian Studies, <www.jstor.org/stable/24738508?seq=1\#metadata_info_tab_contents $>$.

39 Some Chinese soes are known not to have a very good work ethic in Africa or in Kazakhstan raising issues of grab landing and unfair exploitation of natural resources. See Namukale CHINTU, Peter J WILLIAMSON, 'Chinese State-Owned Enterprises in Africa: Myths and Realities' (Ivey Business Journal, April 2013) < https://iveybusinessjournal.com/publication/chinese-state-owned-enterprises-in-africa-myths-and-realities/> .

40 The problem of corruption in this field was addressed in MA Yun, 'Vertical Environmental Management: A Panacea to the Environmental Enforcement Gap in China?' (2017) 1(1) Chinese Journal of Environmental Law, 37.

41 Hong SHENG, Nong ZHAO, 'China's State-owned enterprises. Nature, Performances and Reforms' 2012 (1) World Scientific Series on Economics Research, p. 1-34. See, also, Xinling WAN, 'China's SOE Reform Challenge' The Diplomat (3o November 2017) <https://thedip lomat.com/2017/11/chinas-soe-reform-challenge/>.

42 Matthew MILLER and Fang CHENG, 'China says framework for state-owned enterprise reform "basically complete" (Reuters, 28 September 2017) <www.reuters.com/ article/us-china-soe-reforms/china-says-framework-for-state-owned-enterprise-reform -basically-complete-idUSKCN1C $313 \mathrm{P}>$. 
participation of private investors) or take the form of limited liability or jointstock companies. ${ }^{43}$ If such transitions eventuate, some argue that it will be more difficult for the State to use SoE s for achieving public policy goals. ${ }^{44}$

Of note, according to a Letter of the Ministry of Finance on the Relevant Opinions on the Issue of Recognition of State-owned Enterprises, if the stateowned equity exceeds $50 \%$, this equity shall be in the category of 'state-owned company, enterprise' because it is in an absolute control position. ${ }^{45}$ In other words, a state-owned enterprise is not necessarily a single state-owned entity. Although the operation of an enterprise is not solely determined by the state, because of the large proportion of state-owned entity, national decisions still play an important role. State-owned enterprises can be divided into wholly state-owned enterprises, wholly state-owned companies, and state-owned capital holding companies according to their holdings.

Against this backdrop, it has been pointed out that 'China's strategy has come to rely in significant part on SOE conduct as a tool for implementing rapid change. 46 The soes represent a considerable percentage of the current Chinese economy despite the shrinking of their share value in the market during the last few decades. ${ }^{47}$ Needless to say, these enterprises functionally provide a certain degree of confidence to the Central Government in order to control economic volatility and, above all, social stability nationwide. ${ }^{48}$

43 See $n 26$.

44 'SOEs activities are relevant to climate mitigation in the Chinese economy, particularly in power generation, and steel production sectors' see Henrik BERGSAGER and Anna KORPPOO, 'China's State-Owned Enterprises as Climate Policy Actors: The Power and Steel Sectors', (2013) Nordic Council of Ministers <www.diva-portal.org/smash/get/ diva2:702164/FULLTEXTo1.pdf>.

45 Letter of the Ministry of Finance on the Relevant Opinions on the Issue of Recognition of State-owned Enterprises, <http://jzb.zju.edu.cn/_upload/article/files/d7/17/5ec19c21429f b4a64a5a8c881387/cf5d5234-67fo-444f-b3f9-763edd6f34bc.pdf >.

46 Benoit MAYER, Mikko RAJAVUORI and Mandy Meng FANG, 'The Contribution of State-Owned Enterprises to Climate Change Mitigation in China' (2017) 7 Climate Law 97-124.

47 'Even though their share in the economy continued to decline in the past decade, soes still make up a substantial part of the national economy - roughly controlling 3 o percent of the total secondary and tertiary assets, or over $5^{\circ}$ percent of total industrial assets. The average size of soEs is much bigger than their non-soE peers, with average assets of the former equaling over 13 times of the latter' see Xu GAO, 'State-owned enterprises in China: How big are they?' (The World Bank, 19 January 2010) < http://blogs.worldbank.org/ eastasiapacific/state-owned-enterprises-in-china-how-big-are-they>.

48 Deng FENG, 'Indigenous Evolution of SOE Regulation', in Benjamin L LIEBMAN and Curtis J MILHAUPT (eds), Regulating the Visible Hand? The Institutional Implications of Chinese State Capitalism (Oxford: Oxford University Press, 2016). 
Based on this thinking, soes can be still considered as a useful tool of climate change mitigation and adaptation policy, since these are leading the innovation of the country while paying attention to people's needs as well. Chiefly, soe s are playing a key role, among others, in the transport and energy sectors (including renewable and non-renewable energy). Consequently, the Chinese Government can improve its energy efficiency system by means of soEs inter alia by reducing energy consumption and greenhouse gas emissions. SOEs have the possibility to apply the best available technologies to energy infrastructures. In fact, given their expertise in several vital economic sectors, such as the energy and steel production industries, soe s can significantly help China in meeting its obligations under the Paris Agreement on climate change ratified by the Central Government. Most of the time, soe s can constitute an important component of government capacity building where this is ineffective or not adequate. With these limitations, it seems justified to argue that SOEs' actions can be seen as complementary and harmonized with Central Government policies.

\subsection{Ministry of Ecology and Environment and Environmental Authorities above the County Level}

The Central Government, coordinated with the local authorities, has literally declared 'war on pollution' ${ }^{49}$ Under the push for a Reform of the Environmental Governance originating from the 13th Five-Year Plan, China proclaimed the transformation of the former Ministry of Environmental Protection into the Ministry of Ecology and Environment with powers that include taking on the environmental duties of the land, water, and agriculture ministries. ${ }^{50} \mathrm{Put}$ another way, the central level of national governance now has more direct and comprehensive powers on several environmental-related issues and responsibilities previously held by other organs.

49 Jeff KEARNS, Hannah DORMIDO and Alyssa MCDONALD, China's War on Pollution Will Change the World, 9 March 2018, <https://www.bloomberg.com/graphics/2018-china -pollution/>.

$5^{\circ}$ See further, Jinpeng WANG, 'Reform of China's Environmental Governance: The Creation of a Ministry of Ecology and Environment' (2018) 2(1) Chinese Journal of Environmental Law 112, 114-115.

'China cuts "carbon intensity" $18.8 \%$ in past five years, in effort to rein in emissions' Reuters (2 March 2021) <www.reuters.com/article/china-climatechange/china-cuts-car bon-intensity-188-in-past-five-years-in-effort-to-rein-in-emissions-idUSL $3 \mathrm{~N}_{2} \mathrm{Lo}_{2} \mathrm{HV}>$. See, also, 'Head of China's new environmental watchdog warns of challenges, tight gas supplies' Today (19 March 2018) <www.todayonline.com/world/head-chinas-new -environmental-watchdog-warns-challenges-tight-gas-supplies\#cxrecs_s $>$. 
In order to implement the decision and deployment of the Party Central Committee and the State Council on the establishment of a national carbon emission trading market, the Ministry of Ecology and Environment formulated carbon emission trading management measures for trial implementation. On July 16, 2021, the online trading of China's carbon market was officially launched. This is an important policy tool to promote the achievement of carbon emission peak goals and carbon neutrality. ${ }^{51}$

The Guiding Opinions on Coordinating and Strengthening the Work related to Climate Change and Ecological Environmental Protection (elaborated by the Ministry of Ecology and Environment) set a blueprint for climate change aimed at achieving the goal of ' $\mathrm{CO} 2$ emissions peak by 2030 ' and 'carbon neutrality by 2060.52 In addition, the blueprint was, 'to incorporate the carbon emission impact assessment of high energy consumption and high emission construction projects into the environmental impact assessment system', which means that, in the EIA, the ecological environment departments and other administrative approval departments at all levels must make the effort to coordinate the identification of sources of pollutants and carbon emissions, calculation of source strength, demonstration of feasibility and program comparison of pollution reduction and carbon emission reduction measures, and propose the optimal plan for coordinated control. ${ }^{53}$

For many years, ineffective law enforcement has been a problem that has hindered the achievement of China's environmental rule of law, thus affecting China's ecological environment quality. ${ }^{54}$ Samuel R GINTEL considers that 'the Ministry should no longer tolerate misconduct or violations of relevant laws and procedures realized by local governments in collusion with influential economic groups of interests. 55 Therefore, in the light of ineffective environmental law enforcement, Chinese scholars are of the view that it is better to promote environmental judicial innovation represented by environmental

51 The national carbon emission trading market is officially launched, The State Council, $<$ www. gov.cn/guowuyuan/2021-07/16/content_562559o.htm >.

52 Guiding Opinions on Coordinating and Strengthening the Work related to Climate Change and Ecological Environmental Protection, <www.mee.gov.cn/xxgk2018/xxgk/ xxgko3/202101/t20210113_817221.html>.

53 See Guiding Opinions on Strengthening the Prevention and Control of the Source of the Ecological Environment of High Energy Consumption and High Emission Construction Project, <www.mee.gov.cn/xxgk2018/xxgk/xxgko3/202105/t20210531_835511.html>.

54 Haisong CHEN, 'The Relationship Between Policy and Law in the Transformation of Chinese Ecological Civilization and Rule of Law', (2020) 2 Jilin University Journal Social Sciences Edition 53 .

55 Samuel R. GINTEL, 'Fighting Transnational Bribery: China's Gradual Approach' (2013) 31 Wis Int'l $\mathrm{LJ} 1$. 
public interest litigation and urge the government to perform environmental responsibilities effectively. ${ }^{56}$

With these remarks in mind related to the above-described top-down approach adopted by the Chinese Government, it seems easy to conclude that the top-down approach is the most effective way to address the challenges coming from the environmental field. Certainly, it provides the highest level of control on several sectors of society while drafting a national vision for the long term. However, given the very ambitious targets established by the Central Government, our argument is that it is highly desirable to encourage a set of very proactive and climate change-concerned public institutions to participate in the processes of policy formulation, thus taking advantage of the energies of civil society. That involvement should contribute to more innovative and more widely accepted solutions to mitigate greenhouse gas emissions and address the effects of climate change. Accordingly, the next section explores the possibilities for bottom-up and hybrid approaches.

\section{Evaluating the Adoption of a Bottom-Up Approach in China to Tackle Climate Change}

This section analyses the potential alternative approaches that China could consider in its legislative and political decision-making processes, namely bottom-up and hybrid approaches to more effectively respond to climate change. With the importance of the principle and concept of environmental democracy in mind, the feasibility of the bottom-up approach in China is assessed here, exploring questions about its possible implementation. Furthermore, there are some observations regarding the application of the bottom-up approaches that have been apparent in Italy and Hong Kong (China) thus far.

Several scholars have argued that mitigation and adaptation climate change policies can be better formulated within a framework of multi-level environmental governance. ${ }^{57}$ This entails the adoption of a bottom-up approach. This

$5^{6}$ For example, see Tao BIE, 'A new starting point for environmental public interest litigation legislation', (2013)1 L. Rev. 101.

57 Liliana B ANDONOVA, Michele BETSILL and Harriet BULKELEY, 'Transnational climate governance' (2009) 9(2) Global Environmental Politics, 52-73. Alexander ZAHAR, 'A Bottom-Up Compliance Mechanism for the Paris Agreement' (2017) 1(1) CJEL 69. Rafael LEAL-ARCAS, 'A Bottom-up Approach for Climate Change: The Trade Experience' (2011) 2 Asian JL \& Econ [xxxvii]. 'The Paris Agreement is an experiment in a bottom-up, managerial, transparency-building, and norm-building approach to global cooperation. The 
approach is based on the empowerment of people as well as NGO s that take on the responsibility to participate in legislative and political decision-making processes, contributing to finding solutions together in collaboration with their own political representatives.

Arguing in favour of an effective adoption of a bottom-up approach ${ }^{58}$ and of moving forward to a possible transition from top-down to bottom-up in China, it is necessary to break down barriers of vested interests, in order that all stakeholders, including corporations, national and foreign investors, and civil society networks act in accordance with the relevant legislation. This is not an easy task considering the on-going centralization process driven by the Chinese President XI Jinping.

It should be emphasized at this point that the bottom-up approach under discussion is legally grounded on the concept of environmental democracy, entailing a greater utilization of certain procedural rights, namely, (i) Access to information; (ii) Public Participation in decision-making processes and (iii) Access to Justice in environmental matters. ${ }^{59}$ These three notable democratic procedural rights found legitimacy in the Rio Declaration on Environment and Development 1992. Thus considered, the Rio Declaration can also be

shift in approach is a reasonable gamble in light of the failed efforts over the past two decades to implement the top-down approach under the Kyoto Protocol', see Meinhard DOELLE, 'The Paris Agreement: Historic Breakthrough or High Stakes Experiment?' (2016) 6(1-2) Climate Law 1, 20. 'This Convention employs a bottom-up approach; it focuses on local developmental issues and the marginalized peoples living in the threatened areas. It provides increased international recognition for non-governmental organizations and local land users by obligating states to channel authority and resources to them ... the bottom-up approach in conjunction with creative financing methods will provide a more effective means for dealing with a growing environmental crisis' see Kyle W DANISH, 'International Environmental Law and the Bottom-up Approach: A Review of the Desertification Convention' (1995) 3 Ind J Global Legal Stud 133.

58 BROWN-WEISS has argued: 'The bottom-up approach reflects worldwide developments that empower people to hold leaders accountable. In the bottom-up approach, accountability starts with civil society. In democracy, governments are accountable to the citizens whom they serve. Corporations are increasingly accountable not only to their Board of Directors and to shareholders, but to the public that is affected by their actions. In this view, international institutions are accountable, not only to the States who established them but, importantly, also to the communities and citizens whom they are intended to serve or who are affected by their actions', Edith BROWN WEISS, 'Bottom-up Accountability' (2007) 37 Envtl Pol'y \& L 26o.

59 In the European context, these three concepts are the foundation of the Convention on Access to Information, Public Participation in decision making processes and Access to Justice in environmental matters (Aarhus, 25 June 1998). It entered into force on 30 October 2001, see, Emily BARRITT, The Foundations of the Aarhus Convention, Environmental Democracy, Rights and Stewardship (Bloomsbury Publishing 2020). 
described as the pivotal instrument for the implementation of the bottom-up approach worldwide.

According to Principle 10: 'Environmental issues are best handled with participation of all concerned citizens, at the relevant level. At the national level, each individual shall have appropriate access to information concerning the environment that is held by public authorities, including information on hazardous materials and activities in their communities, and the opportunity to participate in decision-making processes. States shall facilitate and encourage public awareness and participation by making information widely available. Effective access to judicial and administrative proceedings, including redress and remedy, shall be provided' ${ }^{60}$ While this Declaration is considered as soft law, Principle 10 is contemplated by some as legally binding, ${ }^{61}$ or regarded in any case as part of customary law. ${ }^{62}$

Although it might be argued that the Chinese Government has not fully endorsed this principle, with the establishment of the specialist environment divisions of the general courts, the Government has in fact gone some way in providing for access to justice in environmental matters by enabling non-government organizations and provincial and local Environmental Protection Bureaux to sue in the public interest, pursuant to Article 58 of the Environment Protection Law, amended in $2014 .{ }^{63}$ For instance, in 2019, the

6o See further the Rio Declaration on Environment and Development 1992.Jorge E. VIÑUALES, The Rio Declaration on Environment and Development: A Commentary, Oxford University Press, 2015, 287-308.

61 'International community expectations, as reflected notably in the Convention on Access to Information, Public Participation in Decision-Making and Access to Justice in Environmental Matters (Aarhus Convention), the 2010 UNEP Guidelines for the Development of National Legislation on Access to Information, Public Participation and Access to Justice in Environmental Matters and various resolutions of international organizations and conferences, have coalesced to the point where the normative provisions of Principle 10 must be deemed legally binding' see, Günther HANDL, 'Declaration of the United Nations Conference on the Human Environment (Stockholm Declaration), and Rio Declaration on the Human Environment and Development, 1992' (2012) United Nations Audiovisual Library of International Law.

62 See for example, Jean-Marie DUPUY and Jorge VIÑUALES, International Environmental Law, Cambridge University Press (2nd ed 2018) 86-88.

63 Article 58 states: 'For activities that cause environmental pollution, ecological damage and public interest harm, social organizations that meet the following conditions may file litigation to the People's Courts: (1) Have their registration at the civil affairs departments of People's Governments at or above municipal level with subdistricts in accordance with the law; (2) Specialize in environmental protection public interest activities for five consecutive years or more, and have no law violation records. Courts shall accept the litigation filed by social organizations that meet the above criteria. The social organizations that file the litigation shall not seek economic benefits from the litigation'. See further, 
Supreme People's Court issued a typical case of environmental resources. An NGO, China Biodiversity Conservation and Green Development Foundation, sued Shenzhen Sumei Environmental Protection Co. Ltd for selling the socalled 'annual inspection artifact' products that distort the results of the annual inspection of motor vehicle exhausts. ${ }^{64}$ The court held that Sumei's promotional products can circumvent annual motor vehicle inspections through fraudulent methods, abet or assist some motor vehicle owners to commit infringements, and harm the public interest. Therefore, the court pronounced Sumei Company compensated 3.5 million Rмв for air pollution restoration costs (the money is dedicated to addressing air pollution). In addition, the defendants also had to pay the legal costs of the case. Such examples may further encourage qualified social organizations to sue perpetrators of environmental degradation. Although obstacles remain with regard to such actions, public interest litigation can thus contribute to a more effective and efficient environmental legal regime. ${ }^{65}$ From this perspective, judicial decisions can now provoke a higher degree of compliance than in the past. From the Central Government's point of view, environmental litigation is a means of contributing to social control and to solve environment-related issues that affect ordinary people's lives.

Along the same lines, it is possible to agree to some extent with the opinion of some scholars who argue that environmental litigation can contribute to social change equally in a socialist state with Chinese characteristics. ${ }^{66}$ Undoubtedly, touching the red line that divides what is politically permissible and what is not, the recent environmental lawsuits are arguably boosting social activism in a positive way and increasing the importance of the adoption of a bottom-up approach, thus to a degree manifesting the implementation of environmental democracy.

The very fact of the establishment the specialist environmental courts indicates a change to a bottom-up approach, in contrast to a top-down approach - to address environmental issues through the use of law in China.

Richard ZHANG Qing and Benoit MEYER, 'Public Interest Environmental Litigation in China' (2017) 1 Chinese Journal of Environmental Law 202.

64 China Biodiversity Conservation and Green Development Foundation $v$ Shenzhen Sumei Environmental Protection Co., Ltd. and Zhejiang Taobao Network Co., Ltd. for air pollution liability disputes, Typical Cases of Environmental Resources of People's Courts in 2019, $<$ http://www.court.gov.cn/zixun-xiangqing-228361.html>.

65 Yina LIU, 'Friends of Nature and Public Interest Environmental Litigation' (2019) 3 Chinese Journal of Environmental Law 225, 230-231.

66 Benjamin VAN ROOIJ and Mary GALLAGHER, 'China's Top-Down Sources of Law' (2016) 1 China L \& Soc'y Rev 1. 
Further, it is argued that the implementation of the bottom-up approach would also promote greater public participation. This is already shown by the creation of NGO s authorised by government with the mission to provide their scientific contributions and to support the creation of a harmonious society ${ }^{67}$

By way of illustration, in China, there are three general categories of NGOS, namely: (1) Government-Organized (GONGOs); (2) Grassroots NGOs; and (3) International (INGO S). This is an interesting mix which clearly represents a multi-level governance orientation that has great potential to more adequately formulate climate change mitigation and adaptation policies. ${ }^{68}$

It should be observed that in our present context these NGO s do not conduct an equal range of activities due to the considerably imbalanced distribution of economic resources among them. Grassroots NGO s have limited economic resources and work, inter alia, by adopting a State Subcontracting strategy. ${ }^{69}$ Government-organized NGO s have the possibility to be more engaged in organizing advocacy activities and forums of dialogue thanks to the economic subsidies delivered to them by the relevant public authorities. This economic advantage of the Government-organized NGO s can affect - mainly in a negative way - the genuine contributions of the NGO s. However, it should be noted that the All-China Environment Federation, a nationwide non-profit civil society organization in the field of the environment supported by the government has initiated 18 environmental public interest suits to date, while Friends of Nature, a grassroots NGO, has initiated 14 environmental public interest suits. ${ }^{70}$

On a positive note, the cooperation between the Chinese Government and NGO s in the field of climate change has shifted to a new scenario. In fact, the

67 See Articles ${ }^{1-5}$ of Interpretation of the Supreme People's Court on Several Issues Concerning the Application of Law in the Trial of Environmental Civil Public Interest Litigation Cases (in Chinese). See also Runqiu, 'Minister of Ecology and Environment Work Report at the 2021 National Ecological and Environmental Protection Work Conference', <http://www.mee.gov.cn/xxgk2O18/xxgk/xxgk15/202102/t2O21O2O1_819774 .html>.

68 Gabriel CORSETTI, 'How many NGos are there really in China?', China Development Brief, 2019. Chen JIE, 'The NGo Community in China', China Perspectives, (68) 2006, 29-40.

69 Shawn SHIEH, 'Same Bed, Different Dreams? The Divergent Pathways of Foundations and Grassroots N GO s in China' Voluntas: International Journal of Voluntary and Non Profits Organizations (28) 2017, 1785-1811. Carolyn HSU, Fang-YU CHEN, Jamie P HARSLEY and Rachel STERN, 'The state of NGO s in China Today', Brookings, December 15, 2016, <https:// www.brookings.edu/blog/up-front/2016/12/15/the-state-of-ngos-in-china-today/>.

70 The data are based on environmental public interest suits initiated by ACEF and Friends of Nature for ordinary procedure of first instance according to China Judgments Online (<https://wenshu.court.gov.cn>) to 20 August, 2021. 
Climate Change Convention Conference of the Parties held in Copenhagen in 2009 (COP 15) showed that NGO s not only make the general public more aware about climate change effects, but they also contribute to progressing the legislation in order to tackle climate change. In this particular field, the relationship between the Chinese Government and NGO s became more interactive and stable by providing political advice, as noted by WANG: 'Many international NGOS which have branches in China have turned out to be collaborators and allies. The local NGO s have turned to joint action from individual action, actively accumulated action and research experience, and been gradually able to assume the role of monitors as international NGO s. ${ }^{71}$ Thus considered, after years of mutual adaptation, the Chinese Government and the NGO s started various activities guided by common objectives. For instance, 'after the Copenhagen negotiation, the Chinese Government has tried cooperation with the NGO s and the shift from management to governance, providing NGO s more opportunities to participate in formulation of climate policies. ${ }^{72}$

Furthermore, with the adoption of a bottom-up approach, it is argued that greenhouse gas emissions can be more effectively reduced by implementing programs that involve civil society as a whole. ${ }^{73}$ One means for promoting such participation is the Law on Environmental Impact Assessment 2018 (EIA Law). ${ }^{74}$ This tool provides an effective way to implement the environmental legal regime ${ }^{75}$ while at the same time creating the conditions for the promotion of public participation, ${ }^{76}$ which is part of the procedure outlined by the 2018 EIA Law. A proposal concerning projects or activities can be submitted to the relevant public authority for approval after adequate consultation with the

71 Binbin WANG, China's Transition on Climate Change Communication and Governance. From Zero to Hero, Springer, 2021, 97.

72 ibid 106.

73 Maria L BANDA, 'The Bottom-up Alternative: The Mitigation Potential of Private Climate Governance after the Paris Agreement' (2018) 42 Harv Envtl L Rev 325. Kathy Baughman McLeod, 'Building a Resilient Planet: How to Adapt to Climate Change from the Bottom up' (2020) 99 Foreign Aff 54.

74 Law on Environmental Impact Assessment of the People's Republic of China (promulgated on October 28, 2002, amended on 29 December, 2018) <https://flk.npc.gov.cn// detail2.html?ZmY4MDgwODE2ZjEzNWYoNjAxNmYyMGU4OWVmZjE3MGE\%3D>.

75 Giuseppe PODERATI, 'International Standards for Environmental and Social Impact Assessment: Increasing effectiveness of international environmental law' (2021) Rivista Giuridica AmbienteDiritto.it.

76 See, the Interim Measures for Public Participation in Environmental Impact Assessment (promulgated by the State Environmental Protection Agency, 24 February 2006, effective 18 March 2006), Document no 28 of State Environmental Protection Agency (2006). 
public. ${ }^{77}$ This form of public participation, we submit, constitutes an advancement towards a fuller implementation of the bottom-up approach.

Another field where the bottom-up approach could be implemented in China is in the climate-related green energy sector. According to the media, the clean-tech industry and the renewable energy sectors are expected to flourish considerably in the mid-term. ${ }^{78}$ China has the largest market share of this industry at the global level. ${ }^{79}$ This is significant in the fight against climate change, since green sources of energy such as wind and solar contribute massively to the reduction of greenhouse gas emissions. One way to put into practice the bottom-up approach in this particular sector is by involving non-government stakeholders through the formalization of flexible green partnerships or with the elaboration of jointly scientific studies with specific technical operators. Through the formalization of these partnerships, it is argued that China would achieve a low carbon society more quickly. An important factor would be the involvement of think tanks, academic research centres, enterprises and private investors working alongside national authorities. This would contribute to the building up of a synergistic collaboration with local and foreign partners able to combine their own technological expertise and know-how. It is suggested that these kinds of collaborative partnerships would assist China in a more effective way in pursuing sustainable development and mitigating climate change. Multi-level collaboration could grant not only a long term vision but also a very pragmatic one, by increasing the level of responsiveness to climate change. ${ }^{80}$

77 Yuhong ZHAO, 'Public Participation in China's EIA Regime: Rhetoric or Reality?' (2010) 22 (1) Journal of Environmental Law, 89-123.

78 'The European Union, for example, is already forging an alliance with China to implement the Agreement by speeding up the world's transition to clean energy. As renewable energy deployment continues to rise around the world, the alignment of China's capabilities and incentives to invest in the sector positions the country in an even greater leading role for the sector's future', see, Dominic CHIU, 'The East Is Green: China's Global Leadership in Renewable Energy' (CSIS 2017) <https://csisprod.s3.amazonaws.com/ s3fspublic/171011_chiu_china_Solar.pdf?i7ofouep_pGOS3iWhvwUlBNigJMcYJvX>. See, Richard B STEWART and Michael OPPENHEIMER and Bryce RUDYK, 'Building a More Effective Global Climate Regime through a Bottom-up Approach' (2013) 14 Theoretical Inq L 273 .

79 IRENA, Renewable energy prospects: China, Executive Summary, 2014, 3.

80 The Chinese government has promulgated policy to promote multi-level cooperation in the new energy automobile industry, thereby promoting the realization of climate change governance goal. See New Energy Automobile Industry Development Plan (2021-2035) $<$ www.gov.cn/zhengce/content/2020-11/o2/content_5556716.htm>. 
Starting from the top level of government, it is interesting to note the Sino-Italian Environmental Protection Program. ${ }^{81}$ It created an Ecological and Energy Efficient Building joint venture between the Italian and Chinese Governments, involving not only high-level people from the governments but also universities (such as Tsinghua University), private consultants and enterprises. The Sino-Italian cooperation focuses on the construction of sustainable green buildings, sustainable agriculture, transportation, integrated management of water, waste recycling, air quality monitoring, energy efficiency and assistance for China in implementing international conventions. While this cannot be considered an outcome of a conscious adoption of the bottom-up approach, this modus operandi, in trying to involve many different stakeholders, is an example of a participatory model of governance.

\section{Other Experiences Experimenting with the Bottom-Up Approach: (i) Italy and (ii) Hong Kong (China)}

The following brief comparative analysis is intended to demonstrate the universal applicability of the bottom-up approach within different legal and political systems. Despite the differences between the jurisdictions with regard to geography, legal cultures, and traditions, Italy and the Special Administrative Region of Hong Kong offer examples of best practices concerning adoption of the bottom-up approach, putting the political institutions in touch with people's needs. There is an online platform, such as the experience of the Municipality of Lecce, ${ }^{82}$ which is an Internet-based political movement where ordinary people can: (i) submit their contribution to drafting laws and regulations addressing several social issues at the relevant level (for example at the European, national as well as regional levels); (ii) organize e-learning events on civic practices; (iii) set up crowd-funding activities for social purposes; (iv) share ideas regarding areas such as zero waste or circular economy. Insofar as direct democracy can provide a high level of transparency and accountability in the legislative and political decision-making processes, it will help the legal system to harmonize economic development and environmental protection. It

\footnotetext{
81 Sino-Italian Environmental Protection Program <www.sinoitaenvironment.org/2017/in dexE.html>.

82 Teodoro SEMERARO, Nicola, ZACCARELLI, Alejandro LARA, Francesco Sergi CUCINELLI Roberta ARETANO, 'A Bottom-Up and Top-Down Participatory Approach to Planning and Designing Local Urban Development: Evidence from an Urban University Center' (2020), 9(4), Land 98. See, also, Raffaella Y. NANETTI, 'From the Top down: Government Promoted Citizen Participation' (1980) 9 Nonprofit \& Voluntary Sector Q 149.
} 
will also promote an ecological understanding of law, thus contributing to the eco-design of adequate laws and policies to address climate change.

This process can be described as an experimental democracy. It allows citizens to be part of the political decision-making framework, spreading the culture of public participation in a way that is generally not part of the experience of people in countries like China. As reported by US media for example, 'direct democracy, made possible by the Internet, has given a new centrality to citizens rural communities' ${ }^{3}$ This Italian experience could encourage the adoption of the bottom-up approach in China by, inter alia, (i) improving the procedural arrangements for public participation so that the general public (both from rural and urban areas) could have access to laws and regulations made by the Chinese public institutions, and (ii) increasing the implementation of environmental law by increasing ecological awareness of the grass-roots movements.

Another constructive experience - that could be positive for mainland China - is one from the Hong Kong Special Administrative Region. Interestingly, Hong Kong elaborated a special document entitled Hong Kong's climate action plan 2030+, dating from 2018. This document is the outcome of a very intensive dialogue between the political leaders, the private business sector, and the community. Public participation is considered in the document as crucial to fully operationalizing the Paris Agreement. According to the document, Hong Kong is willing to 'reduce carbon intensity by $65 \%$ to $70 \%$ by 2030 using 2005 as a base which is equivalent to $26 \%$ to $36 \%$ of absolute reduction and a reduction to 3.3 to 3.8 tons on a per capita basis' ${ }^{\prime}{ }^{4}$ Other goals are related to the following areas of activity: (i) Mitigating climate change by increasing renewable energy; (ii) Energy and carbon efficiency in buildings and infrastructure; (iii) Lowering carbon emissions from transportation. ${ }^{85}$ Similarly, the Guiding Opinions on Coordinating and Strengthening the Work related to Climate Change and Ecological Environmental Protection set a blueprint of

83 Nathan GARDELS, 'It's time to rethink democracy' The Washington Post (23 March 2018) $<$ www.washingtonpost.com/news/theworldpost/wp/2018/o3/23/directdemocracy/?nore direct $=$ on\&utm_term $=$. agc710795ade $>$.

84 See, 'Carbon emissions and Hong Kong' <https://www.climateready.gov.hk/files/report/ en/2.pdf>. 'The Paris Agreement and Hong Kong' <www.climateready.gov.hk/files/re port/en/1.pdf $>$.

85 Hong Kong Climate, Action Plan 2030+ (Environment Bureau 2017) <www.enb.gov.hk/ sites/default/files/pdf/ClimateActionPlanEng.pdf >. The Environment Bureau will update the "Hong Kong Climate Action Plan" in 2022; see <www.climateready.gov.hk/page .php?id=397>. 
climate change for achieving the goal that ' $\mathrm{CO}_{2}$ emissions peak by 2030' and 'carbon neutrality by 206o' 86

As noted by Matthew Cheung Kin-chung (Chief Secretary for Administration Office, Hong Kong):

Climate change is a cross-sector, cross-domain subject which has farreaching socio-economic and cultural impacts across the globe. As a member of the global village, Hong Kong needs to respond proactively. The current-term Government has set up the high-level Steering Committee on Climate Change to steer and co-ordinate efforts among various bureaux and departments in combating climate change and achieving carbon reduction targets. The committee, having collated a multitude of useful views and perspectives, is committed to taking the task forward. We have got off to a good start and the Paris Agreement will propel us forward in the long run. I encourage everyone in the community to participate actively in this cause. Let us all support an energy-saving, waste-less and low-carbon lifestyle and join hands to build a greener Hong Kong. ${ }^{87}$

China could follow the policy-making model of Hong Kong's climate action plan $2030+$ to involve a wide range of stakeholders and set goals that reflect the adoption of a bottom-up approach. Under this perspective, the Chinese Government might aim to spread environmental awareness, shape education towards the importance of the green economy in order to mitigate climate change, and, more importantly, encourage and facilitate public participation in environmental affairs. ${ }^{88}$

\section{6 \\ Top-Down or Bottom-Up? Is China Using a Hybrid Approach?}

In certain circumstances, the approach adopted by the Chinese Government in tackling environmental matters can be categorized neither as top-down approach nor as bottom-up approaches. In China, it is possible to refer to a manifestation of the hybrid approach by looking at the role played by the mass

\footnotetext{
86 See $\mathrm{n}^{2}$.

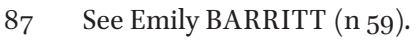

88 'Build a modern environmental governance system led by the Party Committee, the Government with the participation of enterprises, social organization and the public' see Guiding Opinions on Building a Modern Environmental Governance System, The State Council, <www.gov.cn/zhengce/2020-o3/o3/content_548638o.htm >.
} 
media. Broadly speaking, it should be stressed that mass media and public opinions, nowadays, are trying to influence the outcomes of the legislative and political dialogue (with the due difficulties) by speaking up through advocacy activities. The aim would be to better move the authorities towards political decisions that could match with the needs of the people and be more in connection with nature. In China, the mass media and public opinion may be seen as the weakest (or invisible) party of civil society when it comes to exercising some sort of influence. However, the role of the mass media must not be underestimated. In fact, after many scandals (eg, the milk powder scandal,) the Chinese legislature has adopted what is now known as a 'pressureinduced legislation' 89 approach, especially in the food consumer safety area. Consequently, the concerned public, by using media voices, has exerted strong pressure to introduce or amend legislation. Although it is a rare event in the Chinese context, people can, in certain cases, successfully trigger new legislation. ${ }^{90}$ This is a step forward in improving the current system. In relation to the environmental issues, it is possible to assert that pressure-induced legislation is a viable tool to encourage people and public authorities to interact with each other. It enables transparency and public participation. Even though it is not exactly a bottom-up approach, this sign of a hybrid approach can assist in bridging the gap between government officials and ordinary people.

Beyond that, the hybrid approach is currently expanding its range of action, since China's government is working on laws that could increase public participation and also lead to more accountable and transparent public institutions. ${ }^{91}$ In order to have good mitigation and adaptation climate change policies, the

89 Xi ZHANG, 'Towards a More Responsive Legislature: New Media, Public Participation and Pressure-induced Legislation in China' Public Seminar NUS Law School (Singapore, 9 April 2018).

90 Examples include: Sun Zhigang 2003 (Measures on Detention and Repatriation of Urban Vagrants); SARS Virus 2003 (The Emergency Regulation Regarding Emergency Public Health Incidents); HBv Carriers 2003 (The Civil Servant Examination Standards); Xi An 'BMW Sports Lottery 2004' (The Interim Regulations of the People's Republic of China Notary); Inferior Quality 2004 (The Food Safety Law) and so forth.

91 Jonathan R. STROMSETH, Edmund J. MALESKY, Dimitar D. GUEORGUIEV, Lai HAIRONG, Wang XIXIN, Carl BRINTON, China's governance puzzle: Enabling transparency and participation in a single party state (Cambridge University Press 2017). 'We argue that transitioning to clean energy cannot be achieved solely through top-down or bottomup methods; rather, a symbiotic relationship between government or businesses creating opportunities and individual prosumers is key' see, Rafael LEAL-ARCAS, 'Re-Thinking Global Climate Change: A Local, Bottom-up Perspective' (2018) 20 Whitehead J Dipl \& Int'l Rel 4 . 
Chinese Central Government is obliged to engage with several components of civil society. Thus considered, 'primitive' signs of public participation (constituting the hybrid approach) are also within the framework of the aforementioned EIA law (that includes consultation with the public) and the Government-sponsored NGOs (that in some way supervise the engagement and activities carried out within civil society).

It is argued here that a hybrid approach might be considered as a transitional instrument allowing China to shift from an exclusively top-down approach ${ }^{92}$ to a more dynamic and inclusive bottom-up approach. As noted by Steve Rayner, 'advocates of the bottom-up approach are not opposed to national and local governments setting ambitious policy targets that help movement in that direction'. 93

Considering the important role of NGOs in the negotiations, the Chinese Government's attitude to NGOs is more adequate in the field of climate change compared with its attitude in other areas. ${ }^{94}$ In addition to the three major stakeholders (governments, the media and NGOs) in the field of climate change, ${ }^{95}$ WANG Xi, a renowned Chinese scholar, includes the Communist Party for the legal relationship in environmental law stressing the role of third parties (including the Superior Communist Party and Central Government, National People's Congress, the Chinese People's Political Consultative Conference, supervisory committee, public, media, courts, procuratorates) as Supervisors for the Local Communist Party and government as well as enterprises (Figure 1). ${ }^{96}$

Interestingly, the portal website of the Ministry of Ecology and Environment has set up a column entitled 'I Propose Suggestions for the 14th Five-Year

92 John H.S. ABERG 2018 'The myth of the Chinese Authoritarian Model' Global Asia 13 (2), June 2018, 56-59.

93 Steve RAYNER, 'How to eat an elephant: a bottom-up approach to climate policy' (2010) 1o(6) Climate Policy 615-621.

94 See Binbin WANG, ( $\mathrm{n}$ 71).

95 Yunong WU, From Copenhagen to Paris: China's climate governance journey, China Dialogue, July 14, 2021, <https://chinadialogue.net//en/climate/copenhagen-to-paris-chi na-climate-governance-journey/?utm_source $=\mathrm{CD}+$ bilingual+newsletter_Outside+China \&utm_campaign=82fdbe4ff2-EMAIL_CAMPAIGN_2019_O5_23_O3_O3_COPY_o1\&utm _medium=email\&utm_term=o_fea4a231d4-82fdbe4ff2-46905386\&mc_cid=82fdbe $4 \mathrm{f}$ f2\&mc_eid=582deo6226>.

96 WANG Xi, 'A Conceptual Model for China's Environmental Governance: A New Paradigm Tool' (2020) 48 Environmental Protection 13. 


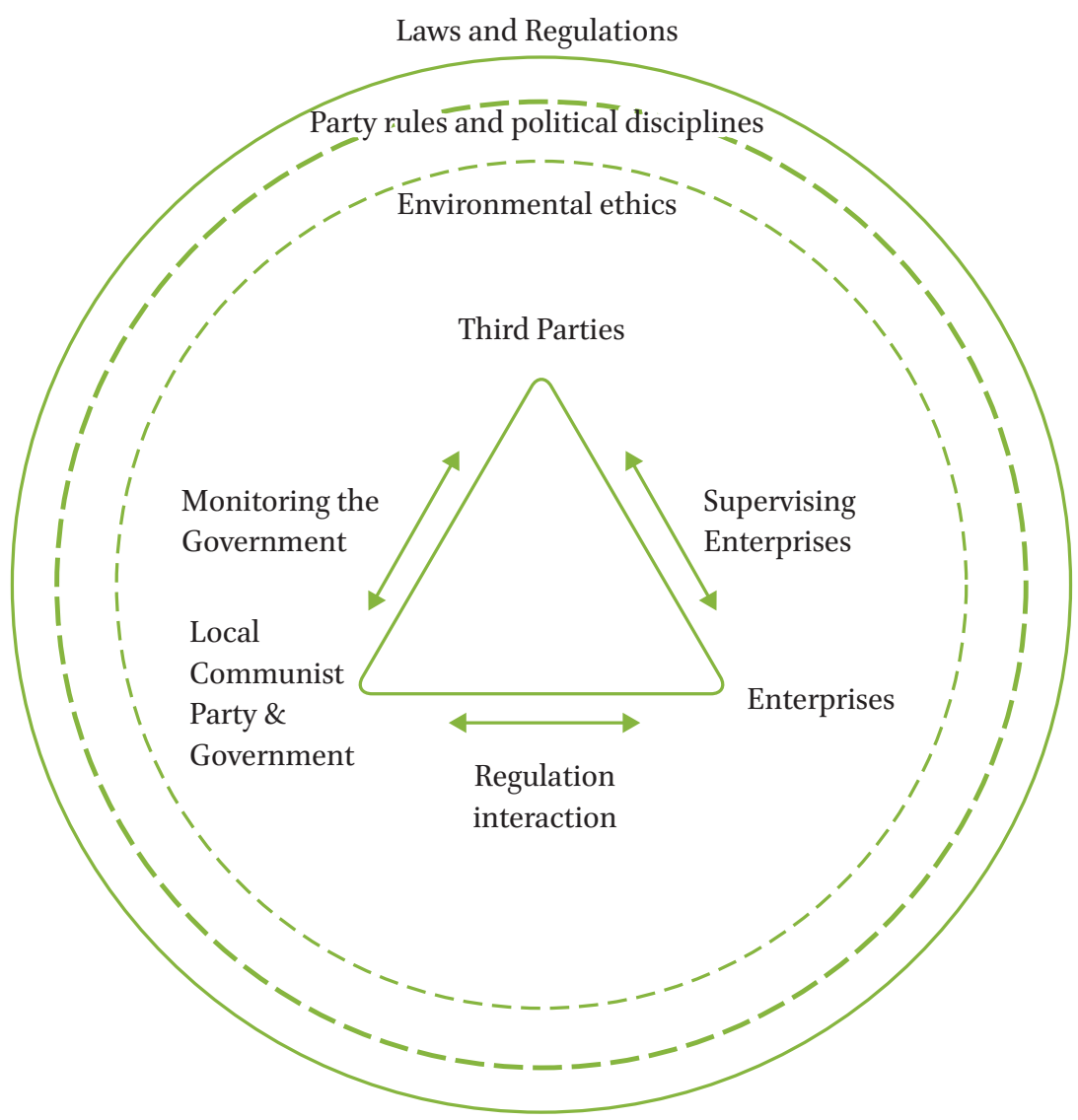

FIGURE 1 Model of environmental governance in China

WANG XI, 'A CONCEPTUAL MODEL FOR CHINA'S ENVIRONMENTAL

GOVERNANCE: A NEW PARADIGM TOOL' (2020) 48 ENVIRONMENTAL

PROTECTION 13; ORIGINAL DIAGRAM REPRODUCED AND TRANSLATED WITH PERMISSION OF PROFESSOR WANG XI

Ecological Environment Protection' to solicit public opinions and suggestions on ecological environment protection through the Internet. ${ }^{97}$

In the opinion of the authors, the main goal for China should be to have a more transparent law-making process that includes public participation at large. Here, it is meaningful to recall the words of MA Jun, Director of the

97 The website lists 15 options that highlight environmental issues, such as heavily polluted weather, black and odorous water, and garbage classification, and the public can select five at the same time according to the priority order. In addition, the public can add other questions that cannot be covered by the 15 options. <www.mee.gov.cn/home/ztbd/2020/ wwsswsthjbhtjy/>. 
Institute of Public and Environmental Affairs, who has argued that although China has achieved some results through the top-down approach, for instance, by delegating inspectors, it is unrealistic to expect to achieve the goal by relying only on the government's action. Therefore, it is necessary to adopt a bottomup approach such as market-based measures to play the role of relevant stakeholders. ${ }^{98}$ For instance, the Chinese Communist Party is taking a hybrid approach to disclosing legislative proposals for public comment. Certainly, this changes the status of the relationship between the private sector (organized in groups or businesses) and the public institutions. ${ }^{99}$

According to recent Chinese practice, from the year 2008, 'the Council of Chairmen of the 11th NPC decided to disclose all legislative bills for comment except for those deemed inappropriate for release (The Legislation Law revised in March 2015 confirmed this decision).'100 This procedure was adopted, among others, for the adoption of the Clean Production Promotion Law (2012).

It is argued that this positive experience shows that it is possible to obtain many positive effects through public participation, namely (i) increase of the quality of law (involvement of experts and qualified people); (ii) effective implementation of the laws (the law is not just imposed, but it matches with people's needs); (iii) possibility to provide interesting feedback on specific issues; (iv) improvement in the dynamics between the concerned public and the state (it is a way to identify common priorities and possibly create the conditions for sustainable development and mitigation of climate change). Our argument is that these points can be interpreted as an on-going slow and monitored transition to a more bottom-up approach or at least a hybrid approach in China. ${ }^{101}$

\section{7}

\section{Conclusions}

Given the magnitude of the problem, it is submitted that climate change policies should be outlined and designed by involving civil society at large, with

98 Summarised from China Global Television Network Interview with MA Jun 'China's Green Efforts: Bigdata to help formulate carbon neutrality strategy', May 20, 2021, <https://www.youtube.com/watch?v=iMgULAd5_ps >.

99 Rafael LEAL-ARCAS, 'Re-Thinking Global Climate Change: A Local, Bottom-up Perspective' (2018) 20 Whitehead J Dipl \& Int'l Rel 14.

100 Xiao ZHU and Kaijie WU, 'Public Participation in China's Environmental Lawmaking: In Pursuit of Better Environmental Democracy' (2017) 29 Oxford Journal of Environmental Law, 3 o May 2017 389-416.

101 See Yuhong ZHAO (n 77); also see Xiao ZHU and Kaijie WU (n 10o). 
participation at all levels, because this is a problem that concerns the whole of humanity, threatening its very existence. By bearing in mind at least two law-making processes, ${ }^{102}$ (namely, theorizing legal principles derived from the jurisprudence or by means of general principles elaborated by high legal authority and subsequently applied to specific cases), this article has argued that it is highly desirable that the Chinese legal system and political decision-making processes should address climate change by means of the implementation of public participation processes as specified in Principle 10 of the Rio Declaration 1992. In view of the urgency of the problem, this would constitute a significant civic advancement. It is argued that more meaningful participation will lead to better climate policies and laws. This is critical to ensure that decisions address citizens' interests in an adequate and equitable manner. Although the Chinese public knows about climate change, ${ }^{103}$ there is still a long way to go from knowing about it to taking corresponding action. ${ }^{104}$ It is difficult to tackle climate change only through a 'managerial model', ${ }^{105}$ which lacks in-depth public participation. Therefore, from this perspective, the adoption of the bottom-up approach or hybrid approach would create a kind of interactive platform, inter alia to link the relevant components of civil society and to gather critical expertise and insights from the general community. This approach would increase transparency and accountability in legislative and political decision-making processes.

Considering that climate change is a multi-level governance problem, it must be solved by inverting the pyramid that traditionally describes civil society. Thus, it is crucial to consider the views of the lowest levels of the pyramid,

102 'These two processes are, respectively, adjudication and legislation. Each process highlights and hides different aspects of a legal problem. The single-case perspective of adjudication can seem narrow, and hence inferior to the broad perspectives that legislatures can incorporate into their decision-making processes. The adjudicative approach, however, has advantages that are less obvious. Notably, the adjudicative process is more likely to facilitate the adoption of simple, elegant rules for decision making. The assessment of which approach is superior is therefore indeterminate. Each has its strengths and weaknesses that make it more or less appropriate for different contexts' see, Jeffrey J RACHLINSKI, 'Bottom-up versus Top-down Lawmaking' (2006) 73 U Chi L Rev 933.

103 'About $98.7 \%$ of the interviewees support the climate change-related education at schools' see Binbin WANG (n 71) 139 .

104 See Yunong WU (n 95).

105 'Managerial model is based on a planned economy and centralized political system. And decision-making agendas and goals are passed down from higher to lower levels' Xixin WANG, Yongle ZHANG, 'The Rise of Participatory Governance in China: Empirical Models, Theoretical Framework, and Institutional Analysis', (2018) U. PA. ASIAN L. REV. $25^{-26 .}$ 
making it possible to bring innovative solutions to the top level. The bottomup approach or hybrid approach dynamics might take more time. However, in today's world, communication is faster than ever before in human history, and that can allow law to be made on the basis of wide-ranging debates among various involved local communities having competing visions with regard to specific matters. Strengthening of the bottom-up path requires scientists and researchers to act as a bridge between the public and the government, thereby increasing the public's recognition of government decision-making and improving behaviours in response to climate change. Therefore, law can develop, itself becoming the creation of several interactive political organs, agencies, courts and individuals working together to solve climate changerelated issues and stimulating and creating strong resilience around these imperative issues. Public participation can strengthen the legitimacy of administrative decision-making, and align climate change-related policies and laws with public awareness and interest needs, which improves the acceptability of new norms and related legal mechanisms. Although policies and laws can provide a good regulatory basis for climate change, the interests of the concerned parties should be expressed and taken into account. This will better promote the implementation of the law and the achievement of appropriate and just outcomes in Chinese society in the area of climate change. 